being sought. Among the faits accomplis of Canadian chemists may be mentioned standardization of tests for honey, improved maple produots, a method of drying apples and other fruits with better retention of flavour, and a wax mixture for use in plucking poultry.

Dr. N. H. Grace dealt with projects and achieve. ments in the field of biology. Growth-promoting substances are now added to the dusts used for disinfecting seeds. The development of rust-resistant varieties of wheat is estimated to have saved the prairie provinces about 38 million dollars this year. Research is proceeding on the factors that determine the malting quality of barley with the view of growing more barley of better quality. In 1937 , some 80,000 tons of bacon were sent to Britain, prepared in twentysix plants, each using its own method; research is now being directed towards improving both quality and uniformity.

Methods have been developed for altering the heritable characters of plants by heat and chemical treatment, and progress in producing a droughtresisting and soil-binding forage crop for western Canada has been effected by crossing a Russian grass with the best Canadian wheat varieties. From poplars and conifers it is hoped to produce, by crossing, rapid-growing varieties of trees possessing hybrid vigour and disease-resistance that may be vegetatively propagated with the aid of 'plant hormones'.

\title{
Admiralty Laboratories at Sheffield
}

T HE new Admiralty Laboratories at Janson Street, Sheffield, were opened on December 15 by Sir William Bragg, president of the Royal Society.

These laboratories, which have been constructed to cope with the ever-increasing amount of Government work, are designed in such a fashion as to incorporate all recent developments in laboratory architecture. The two large analytical laboratories, for ferrous and non-ferrous analysis respectively, embody many unusual features. One was struck with the arrangements which have been made for the conducting of chemical analysis on a large scale; indeed the expression 'mass-production' might be used with respect to the systematizing of analytical methods, certain benches, for example, being given up solely to determinations of one particular element. The carbon combustion room was particularly intriguing in its lay-out, containing several combustion apparatus all set in a line and arranged for rapid analysis of carbon in steel. A particular feature is made of spectrographical analysis, for which purpose Hilger quartz spectrographs are used. This method of analysis has been brought to a high state of efficiency, and complete reliance can be placed on the results obtained.
One was particularly impressed not only by the orderly and systematic arrangement of plant and apparatus, but also by the system with which the work is carried out; even the chemical store is a model of order and forethought. The heat-treatment laboratory, containing Birlec and Wild-Barfield hightemperature furnaces with temperature control devices, supplies all that is required for experimental heat-treatment purposes, and it is understood that a high-frequency furnace is shortly to be installed. One of the most pleasing features is the lighting, the lower half of the windows being of Thermolux glass, which provides insulation from both heat and from the glare of the sun, whilst the walls of the labora. tories are of a very pleasing tone of semi-glazed fireclay tiles. The air-conditioning system is novel, and no signs of fumes can be detected anywhere in the laboratories.

These new laboratories are capable of turning out all the work that is necessary, and their constructional arrangement has considerably speeded up the rate of analysis. They are most pleasing premises to work in, and those in authority are to be congratulated on this new development, which is significant of the scientific progress in metallurgical work for which the Admiralty has been responsible in the past.

J. H. A.

\section{British Institute of Radiology}

\section{Annual Congress}

\begin{abstract}
THE twelfth Annual Congress of the British Institute of Radiology was held in the Central Hall, Westminster, on December 7-9, and in connexion with the Congress there was an exhibition of apparatus organized by the British X-ray industry. The Congress was opened by the president, Mr. W. E. Schall, the opening address being followed by the nineteenth Mackenzie Davidson Memorial Lecture, delivered by Dr. G. Shearer on " $\mathrm{X}$ rays-Their Influence in Pure and Applied Science". In the course of this lecture, Dr. Shearer noted that twentyfive years have elapsed since Moseley first observed the regularities in the $K$ and $L \mathrm{X}$-ray spectra of the
\end{abstract}

elements which pointed to the general similarities in the internal structures of various atoms and led ultimately to a fairly complete understanding of atomic structure and to the placing of electrons in their appropriate energy levels. This same series of observations has also led to the use of X-rays in the study of the solid state, with results of great practical and industrial importance. From the study of simple crystals by W. H. and W. L. Bragg, the work has advanced to such an extent that complex molecules such as the proteins can now be studied, and the results, incidentally, linked up with the work of the organic chemists. Another phase of X-ray work 